J.M. Wit, E.J. van Kalsbeek*, J. van Wijk-Hoek*, G.J. Leppink*. Department of Paediatrics, division of Endocrinology, and Department of Mathematical Statistics, State University, Utrecht, The Netherlands. ASSESSMENT OF THE USEFULNESS OF WEEKLY KNEMOMETRIC MEASUREMENTS IN GROWTH STUDIES
110

J.Knudtzon*, D.Aarskog

Department of Pediatrics, University of Bergen, Bergen, Norway.

\section{ESTROGEN TREATMENT OF TALL GIRLS WITH MARFAN} SYNDROME

Patients with Marfan syndrome have disproportionate growth and often increased adult heights with progressive kyphoscoliosis. Five girls with Marfan syndrome were treated with estrogen in order to reduce their final heights. Treatment was started at a chronological age of $11.9 \pm 0.5$ years (mean \pm S.E.M.) and bone age (Greulich-Pylē) of $12.4+0,9$ yēars, when their heights were $173.0+3.1 \mathrm{~cm}$ (> 3 S.D.).

Bayley-Pinneau and Tanner 1 height predictions were $186.2+1.4 \mathrm{~cm}$ and $183.0+1.2 \mathrm{~cm}$, respectively. Estrogēn treatment for $2.0+0.4$ years resulted in menarche.at the age of $12.9^{-} \pm 0.4$ years and heights at end of treatment of $179.4^{-}+1.4 \mathrm{~cm}$. Final heights were $180.6+2.0 \mathrm{~cm}$. No side-ejffects were observed. The growth reductions for the two prediction methods for adult height represent $42 \%$ and $24 \%$ of the estimated growth potential before treatment. Although the methods for bone age assessment and prediction of adult height are based on data for healthy children. the present results indicate that estrogen treatment may be effective in reducing adult height in girls with Marfan syndrome. Potential beneficial effects on the development of scoliosis remain to be clarified.

\section{E.Schoenle*. G. Theintz. T.Torresani. M.Muritano*} P.C.Sizonenko. R.Illig Department of Paediatrics, University of Zurich. and Department of Paediatrics and Genetics. University Hospital Geneva. Switzerland

LACK OF BROMOCRIPTINE-INDUCED REDUCTION OF GROWTH PREDICTION IN TALL ADOLESCENTS

It has been suggested that bromocriptine treatment of tall of BA is Tanner-Whitehouse (Tw2) tage is that it is laborious and requires trained staff. A method based on computer analysis of bone shape as indicator of maturity has been developed. The representative patterns of each maturity stage of the TW2 atlas have been digitized by means of a graphic board. The computer calculates the gravity center of the figures and representes the vectorial radius from the center of gravity to the point of the bone perimeter for each digitized point on a coordinate axis. The degrees of each vector $(0-3608)$ correspond to axis $X$ and the length of each vector to axis $Y$. The unified extremes of the vectors result in a representative curve of the bone shape. The comparison of a problem curve with the catalogue of standard curves of TW2 atlas has demonstrated that this method is easier than the classic method. The automatic comparison of the curves and imaging by video VICOM system is possible. The method is also being applied for the tarsal BA of newborns.

109 Z. Dickerman, M. Kalijman*, R. Keret*,A. Silbergeld*, B. Bauman*, A.Zacharia*, Z. Zadik*+, Z. Laron. Inst. Ped. Adolesc. Endocr., Beil inson Med. Ctr., PetahTikva, Sackler Sch. Med., Tel Aviv Univ. \& Dept. Ped. $\mathrm{A}^{+}$, Kaplan Med. Ctr., Rehovot, Israel. 24-HOUR GH SECRETION PATTERN IN FAMILIAL TALL STATURE

GH secretion was measured by 30 mins. sampling over $24 \mathrm{hrs}$ (using a Cormed pump) in 3 tall girls (aged 12,14 \& 16 yrs), belonging to a family of tall stature ( 4 of 7 sibs \& parents were above 90 th centile). In all the sibs an iv TRH bolus (200 $\mathrm{mcg}$ ) caused a rise of plasma GH from $3 .+1.5$ to $58 .+67 . \mathrm{ng} / \mathrm{ml}(\mathrm{m}+\mathrm{SD})$. The 24-hrs GH secretion pattern was compared to 2 matched control subjects:

$\begin{array}{lcccc} & \text { Pulses/24hr } & \frac{\text { Max.peak GH }}{(n \mathrm{ng} / \mathrm{mI})} & \frac{\text { IC }- \text { GH }}{(\mathrm{ng} / \mathrm{ml})} & \text { AUC } \\ \text { Patients } n=3 & 6-8 & 70-130 & 12-24 & 604-1172 \\ \text { Controls } n=2 & 6-8 & 20-22 & 5-8 & 280-314\end{array}$
(IC= integrated concentration; AUC = area under the curve)

Fasting serum IGF-1 levels were elevated in 2 girls aged 11 $(37 \mathrm{nM} / 1)$ and 15 yrs $(48 \mathrm{nM} / 1)$, and with in the normal range in the rest of the sibs (16-43 nM/1), and in the parents (16.5 \& $24.2 \mathrm{nM} / 1)$, with a significant correlation to their basal GH levels $(r=.85, p<.02)$.

In conclusion, the pattern of GH secretion in several members of a family with tall stature was reported. In all the siblings an abnormal GH response to TRH and in 3 tested an increased daily output of $\mathrm{GH}$ was found. girls and boys reduces growth prediction by inhibiton of growth hormone secretion ( $\mathrm{J} \mathrm{Cl}$ in Endocr Metab 58.1022-1026.1984). We have treated 15 girls and 5 boys (chron.age 10.1-14.6 years. bone age $11.0-14.0$ years) with bromocriptine $(2 \times 2.5 \mathrm{mg} /$ day $)$ over a period of $1.14 \pm 0.31$ years $(0.6-1.75)$ mean adult height prediction before and after bromocriptine were $-0.8 \pm 3.5 \mathrm{~cm}$ according to Bailey-Pinneau $(p=0.433)$. and $+0.2 \pm 2.5 \mathrm{~cm}$ according to Tanner Mark $I_{+}(p=0.586)$. The mean peak GH values after TRH i.v. were $53.0 \pm 50.2 \mathrm{mU} / 1$ before. and $59.0 \pm 50.2 \mathrm{mU} / \mathrm{l}$ during bromocriptine treatment $(p=0.314)$. The wide range of the $\mathrm{GH}$ results most probably reflects physiological variations in this age group. Our results are essentially negative. Moreover. the concept. that bromocriptine reduces $\mathrm{GH}$ secretion. seems doubtful: in 6 of our patients we have measured plasma GH after $2.5 \mathrm{mg}$ of bromocriptine and found a significant increase within the first three hours.

our results do not support the data from the literature. We conclude. that bromocriptine is ineffective in reducing adult height of tall girls and boys.

Supported by Swiss National Science Foundation grant 3.906.083.

\section{H.P. Schwarz, E. Joss, K. Zuppinger} Department of Pediatrics, University of Bern, Inselspital, Bern, Switzerland. BROMOCRIPTINE (BRC) TREATMENT IN EXCESSIVELY TALL BOYS. A PAIR-MATCHED CONTROLLED STUDY

Recently, BRC has been proposed as a novel agent for the treatment of tall stature in adolescents based on its ability to reduce adult height prediction (HP). Eight boys with a chronological age of 10.3-15.4 yrs (mean $13.3 \mathrm{yrs}$ ) were treated for 1 yr with BRC $7.5 \mathrm{mg}$ daily. At the onset of therapy, adult height prediction according to Bayley-Pinneau (HP-BP) was 200.7 to 209.7 cm and according to Tanner Mark II (HP-TWII) 199.0-211.5 cm. After 1 yr of therapy, HP with both methods had decreased in every boy, changing by $-4.13+$ $1.86(\mathrm{SD}) \mathrm{cm}$ (HP-BP) or $-3.35+2.39$ (SD) $\mathrm{cm}$ (HP-TWII), respectively. To substantiate these findings, each patient was pair-matched with a control, an untreated boy with a height above +2SDS and a bone age differing less than $0.5 \mathrm{yr}$. HP-BP was significantly reduced in patients after 1 yr of BRC compared with their matched controls after 1 yr of follow-up (p less than 0.02). By contrast, differences in HP-TWII were not significant. Because of this discrepancy it is uncertain whether final height in tall boys will really be reduced by treatment with $\mathrm{BRC}$.

BRC was kindly provided by Dr. R. Schmidt, Sandoz Ltd.
Results (paired Wilcoxon rank test): The differences between the 